\title{
Expectations and quantitative easing in the Eurozone
}

\author{
Nicholas Apergis* \\ University of Piraeus, Greece
}

Received: 18 January 2018

Revised: 11 April 2018

Accepted: 11 April 2018

\begin{abstract}
The European economy suffered from both the 2008 financial crisis and the sovereign debt crisis in certain of its members, while it experienced a period of QE starting in 2015. The goal of this study is to explore the direct and exclusive effects of this unconventional monetary policy on financial markets, economic activity, and labor markets across the Eurozone. The analysis employs the Markov-Switching Dynamic Regression method. The findings illustrate the effectiveness of QE to reduce short- and log-term credit spreads, increase stock prices, improve market expectations, recover labor market conditions and economic productivity, with the findings emphasizing the confidence/expectations mechanism as the primary transmission channel of the QE policy.
\end{abstract}

Keywords: expectations channel; quantitative easing monetary policy; Markov-switching dynamic regression model; Eurozone countries

JEL Classification Codes: E52, E20, C24

\section{Introduction}

Over time, many central banks have implemented quantitative easing (QE) programs to counter the stressful effects of shocks on the economy, i.e. the QE program in the US, known as the large-scale asset purchase (LSAP) program, the QE program adopted by the Bank of Japan, and the corresponding QE program implemented by the European Central Bank (ECB) as a response mainly to the sovereign debt crisis in the Eurozone.

The literature on the effectiveness of those programs documents two conflicting views: according to the traditional liquidity trap view, when interest rates are close or at their lower bound, loose monetary policies are ineffective (Adam and Billi, 2006; Schmitt-Grohé and Uribe, 2007). By contrast, loose monetary policy is very positive for the economy, even in the case at or close to the lower bound, since the implementation of such loose policies can alter market expectations (Bernanke and Reinhart, 2004). In terms of this latter factor, there is a long tradition in macroeconomics that business cycles may be primarily driven by bouts of optimism

\footnotetext{
*E-mail: napergis@unipi.gr.

Citation: Apergis, N. (2018) Expectations and quantitative easing in the Eurozone, Economics and Business Letters, 7(1), 18-23.
} 
and pessimism (Beaudry et al., 2011). Despite the belief that changes in confidence and expectations can be an important business cycle driver, it is controversial in macroeconomics (Leduc, 2010), partly because it is difficult to measure its importance empirically. However, Angeletos et al. (2015) provide evidence of the strong role for confidence in explaining the business cycle. In addition, monetary policy might help restoring confidence in the financial system. As a consequence, risk premia and uncertainty might decline, with a positive effect on asset prices (Eggertson and Woodford, 2003; Krishnamurthy and Vissing-Jorgensen, 2011).

D'Amico and King (2013) provide supportive evidence for the success of the Fed's Treasury program in improving bond market liquidity and, thus, contributing to the reduction in the cost of credit, which had substantial stimulating effects for the macroeconomy. Although Neely (2015) document that the Fed's unconventional monetary policy announcements in 2008-2009 substantially reduced long-term bond yields and the spot value of the dollar, they support that these changes are due to the portfolio choice transmission mechanism and that these policy announcements do not appear to have reduced yields by reducing expectations of real growth. In other words, their findings provide evidence for the ineffectiveness of the expectations transmission mechanism.

To the best of our knowledge no study has explored the effectiveness of the expectations factor in the case of the ECB's QE. Hence, the goal of this paper is to quantitatively explore the direct effects of the Eurozone QE program on the macroeconomy and financial markets by assessing its expectations mechanism by using the Markov-switching dynamic regression (MSDR) modeling approach. Mishkin (2004) argues that central bank decisions about the future path of short-term interest rates affect economic agents' views. Agents' expectations are highly dependent on their beliefs about the credibility of the central banks. If they believe that the central bank is serious about inflation, their expectations on future prices will be anchored around the central bank inflation targets.

This work is close to those by: i) Gambetti, and Musso (2017) who provide empirical evidence on the macroeconomic impact of the QE program announced by the European Central Bank in January 2015. Their evidence suggests that the program had a significant upward effect on both real GDP and inflation in the euro area during the first two years, while several channels of transmission appear to have been activated, including the portfolio rebalancing channel, the exchange rate channel, the inflation re-anchoring channel and the credit channel, ii) Koijen et al. (2016) who explore the impact of the Eurozone QE program on risk exposures and asset prices; their results suggest that while QE programs can be used to provide accommodation at the lower bound, they may raise risks in relevance to financial stability, and iii) Altavilla et al. (2015) who also evaluate the effects on asset prices and assess its main transmission channels; their findings document that the impact of the QE program on asset prices is sizeable, while they provide evidence of the reinforcement of other transmission channels.

\section{Literature review}

To stress the importance of the expectations channel, Woodford (2001) argues that in a credible monetary policy regime, any commitments to raise interest rates in response to inflationary pressures are sufficient for forward-looking economic units to bring about the required contraction in aggregate demand, while Blanchflower (2008) documents that the future path of prices is correlated with an individual's evaluation on current prices. Carlstrom et al. (2012) and Del Negro et al. (2013) find large effects on output and inflation from the management of expectations of future interest rates. Their findings suggest that long-term interest rates drive these macroeconomic effects. Filardo and Hofmann (2014) also highlight that historically, forward guidance has a significant effect on interest rate expectations even at the zero lower bound, which can provide additional monetary stimulus. However, the literature has not investigated 
the effect of the ECB's QE program on the Eurozone macroeconomy and financial markets, which is the primary goal (and novelty) of this study.

\section{Methodology}

The Markov-Switching Dynamic Regression (MSDR) model captures non-linearity or asymmetry in the process that drives the adjustment of variables to monetary base shocks. This modeling approach is useful in cases where the adjustment seems to be primarily driven by exogenous events. We assume that the methodological approach is based on bivariate models in which the independent variable is the monetary base (across all models) and the dependent variable is the proxies for the financial and macroeconomic variables. Each of these dependent variables follows a process that depends on the value of an unobserved state variable, $s_{t}$. We assume that there are $M=2$ regimes (prior and after the implementation of QE), and hence when $s_{t}=m$, for $m=1$ or 2 , the analyzed variable is in state or regime $m$ in period $t$. The two-regime MSDR model for the dependent variable $\mathrm{y}$ is specified as follows:

$$
y_{t}=\mu(m)+\sigma(m) \varepsilon_{t}
$$

where $\varepsilon_{t}$ follows an independent and identically distributed standard normal distribution. In addition, the expressions of the mean, $\mu(m)$, and the volatility, $\sigma(m)$ indicate that both $\mu$ and $\sigma$ are regime dependent. In this model, the probability of transitioning from regime $i$ in period $t-1$ to regime $j$ in period $t$ is expressed as follows: $P\left(s_{t}=j \mid s_{t}-1=i\right)=p_{i j}(t)$, where in our case the matrix of transition probabilities, $p(t)$, yields:

$$
p_{t}=\left[\begin{array}{ll}
p_{11}(t) & p_{12}(t) \\
p_{21}(t) & p_{22}(t)
\end{array}\right]
$$

We treat the initiation of QE on January 22, 2015 as exogenous with respect to triggering a regime switch for the MSDR process. The Regime Classification Measure (RCM) offered by Ang and Bekaert (2002) can determine the accuracy of the MSDR model. The statistic ranges from 0 (perfect regime classification) to 100 (failure to detect any regime classification), with lower values being more preferable.

\section{Data}

Monthly data on money supply (M3), industrial production (IP), the capacity utilization ratio (CUR)-the ratio indicates the degree of utilization of plant and equipment, with a higher CUR identifying greater economic activity in the Eurozone, and labor market conditions (UN), measured by the unemployment rate in the Eurozone. Data on variables that reflect Eurozone's credit market conditions are also obtained, i.e. short-term credit spread (SSPR)-the difference between short-term German yields and the 2-year Italian sovereign public bond yields, and the longterm credit spread (LSPR)-the difference between short-term German yields and the 10-year Italian sovereign public bonds yields. The two spreads proxy for the risk aversion of market participants. Data on the stock market index are obtained (SPR), reflecting the market expectations in relevance to the future stock market and economic conditions and measured through the Euro Stoxx 50 Index. Data are obtained from Datastream and span the period 2001-2017.

\section{Empirical analysis}

The first part of the empirical analysis applies the Elliott et al. (1996) DF-GLS unit root methodology (Table 1). All variables reject the null hypothesis of stationarity, indicating the presence of a unit root. 
Table 1. Unit root tests (DF-GLS test).

\begin{tabular}{lrr}
\hline \hline Variables & Levels & First differences \\
\hline$M$ & -1.28 & $-4.62^{* * *}$ \\
$I P$ & -1.33 & $-4.98^{* * *}$ \\
CUR & -1.37 & $-5.15^{* * *}$ \\
UN & -1.26 & $-4.81^{* * *}$ \\
SSPR & -1.39 & $-4.77^{* * *}$ \\
LSPR & -1.35 & $-4.86^{* * *}$ \\
SP & -1.24 & $-5.48^{* * *}$ \\
\hline \hline
\end{tabular}

Note: $\mathrm{M}=$ money supply-M3, IP = industrial production, CUR = capacity utilization ratio, UN = unemployment rate, $\mathrm{SSRP}=$ short-term credit spread, LSRP $=$ long-term credit spread, $\mathrm{SP}=$ stock prices. $* * * \mathrm{p}<0.01$.

Table 2. QE and macroeconomic and financial variables-MRSD estimates (normal distribution for the errors).

\begin{tabular}{l|rrr|rrr}
\hline \hline Variables & \multicolumn{4}{|c|}{ State 1 (prior to QE) } & \multicolumn{3}{c}{ State 2 (after QE) } \\
$\mu$ & $\sigma$ & LL & $\mu$ & $\mu$ & $\sigma$ & LL \\
\hline$I P$ & 0.459 & 0.583 & -1073.2 & 1.328 & 0.594 & -1349.4 \\
& {$[0.01]$} & {$[0.00]$} & & {$[0.00]$} & {$[0.00]$} & \\
CUR & 0.236 & 0.527 & -936.5 & 0.522 & 0.560 & -966.2 \\
& {$[0.01]$} & {$[0.00]$} & & {$[0.00]$} & {$[0.00]$} & \\
$U N$ & 0.189 & 0.560 & -988.2 & -0.453 & 0.595 & -995.9 \\
& {$[0.02]$} & {$[0.00]$} & & {$[0.00]$} & {$[0.00]$} & \\
SSPR & -0.073 & 0.615 & -1134.6 & -0.416 & 0.652 & -1451.8 \\
& {$[0.02]$} & {$[0.00]$} & & {$[0.00]$} & {$[0.00]$} & \\
LSPR & -0.086 & 0.593 & -963.1 & -1.248 & 0.566 & -912.6 \\
& {$[0.02]$} & {$[0.00]$} & & {$[0.00]$} & {$[0.00]$} & \\
SP & 0.226 & 0.626 & -981.5 & 1.416 & 0.653 & -1126.7 \\
& {$[0.01]$} & {$[0.00]$} & & {$[0.00]$} & {$[0.00]$} & \\
\hline \hline
\end{tabular}

Note: $\mathrm{IP}=$ industrial production, $\mathrm{CUR}=$ capacity utilization ratio, $\mathrm{UN}=$ unemployment rate, $\mathrm{SSRP}=$ short-term credit spread, LSRP = long-term credit spread, SP = stock prices. LL is the maximized log likelihood. Figures in brackets are p-values.

Table 3. Transition probabilities (a normal distribution in the errors).

\begin{tabular}{lrrrrr}
\hline \hline Variables & $p_{11}$ & $p_{12}$ & $p_{21}$ & $p_{22}$ & RCM \\
\hline$I P$ & 0.781 & 0.203 & 0.228 & 0.812 & 37.93 \\
CUR & 0.862 & 0.095 & 0.078 & 0.883 & 48.71 \\
UN & 0.684 & 0.052 & 0.063 & 0.581 & 35.48 \\
SSPR & 0.895 & 0.138 & 0.214 & 0.911 & 21.04 \\
LSPR & 0.862 & 0.127 & 0.160 & 0.884 & 23.72 \\
SP & 0.839 & 0.106 & 0.125 & 0.894 & 19.62 \\
\hline \hline
\end{tabular}

Note: IP = industrial production, CUR = capacity utilization ratio, $\mathrm{UN}=$ unemployment rate, $\mathrm{SSRP}=$ short-term credit spread, $\mathrm{LSRP}=$ long-term credit spread, $\mathrm{SP}=$ stock prices. $\mathrm{RCM}=$ the regime classification metric.

Table 2 reports the MSDR estimates. All rows include the estimation results for the prior to QE and after QE regimes for both the macroeconomic and financial market variables in terms of their mean and volatility. The QE event retains the sign of the effect of money supply changes on both types of variables over the state following the QE regime. The largest switching occurs for the case of stock prices (from 0.226 to 1.416$)$, followed by long-term spreads ( -0.086 to 1.248), indicating that $\mathrm{QE}$ had a strong impact on asset prices, confirming the validity of the expectations mechanism. The results also suggest that industrial production and labor market conditions in the Eurozone recovered after the launch of QE (from 0.459 to 1.328 for industrial production and from 0.189 to -0.453 for the unemployment rate), while it decreased both short(from -0.073 to -0.416 ) and long-term credit spreads. 
Overall, the findings clearly illustrate that QE reduced both short- and long-term credit spreads, thus, decreasing the risk aversion in the European bond markets, while it drove up stock prices, thereby, improving confidence/expectations in the stock market and future economic conditions in the Eurozone. To the extent that the risk aversion in bond markets decreased and stock prices rose due to the recovery in financial market confidence, this lead to a decreased unemployment rate; at the same time, the stock market recovery is associated with (positive) changes in market expectations which boosted the industrial production, as well as the capacity utilization. Hence, the findings consider that the recovery of the Eurozone economy during the QE period was mainly through the confidence/expectations channel, since both stock prices and credit spreads are strongly associated with expectations regarding the future evolution of financial markets and the macroeconomy.

Table 3 presents the estimates of the smoothed transition probabilities. They indicate that each regime is substantially persistent, as evidenced by the large regime probabilities $\mathrm{p}_{11}$ and $\mathrm{p}_{22}$. In the case of unemployment, the findings indicate a lower persistent, implying that although the QE program managed to fight unemployment, labor markets in the Eurozone need higher flexibility and further reforms, i.e. reducing long-term unemployment and/or increasing labor market mismatches (Task Force, 2012). The RCM values are smaller for the case of financial variables, indicating that $\mathrm{QE}$ had a stronger effect on switching in relevance to the financial than the macroeconomic variables.

\section{Conclusion}

This study investigated the effects of the Eurozone's QE program on a range of variables, including economic activity, labor, credit market conditions, and stock market prices. The findings indicated that the QE mechanism improved credit market conditions, due to favorable declines in the risk aversion. Moreover, QE increased stock prices, indicating that market expectations for future economic conditions were recovered. QE also improved labor market conditions and had a positive effect on economic activity.

As stock prices and credit spreads are strongly related to confidence and expectations, the results emphasize the importance of expectations. The application of the QE pushed the Eurozone into the regime for improved economic and financial variables. The recovery in expectations was a key factor for stimulating economic activities and improving financial market conditions. The empirical evidence showed the importance of expectations management, the signaling effect, and regime changes through monetary policy. These findings could be useful in designing future monetary policies in a rapidly changing and highly integrated global economy.

\section{References}

Adam, K., and Billi, R.M. (2006) Optimal monetary policy under commitment with a zero bound on nominal interest rates, Journal of Money, Credit and Banking, 38, 1877-1905.

Altavilla, C., Carboni, G., and Motto, R. (2015) Asset purchase programmes and financial markets: evidence from the Euro area, ECB Working Paper, No 1864.

Ang, A., and Bekaert, G. (2002) Regime switches in interest rates, Journal of Business and Economic Statistics, 20, 163-182.

Angeletos, G.M., Collard, F., and Dellas, H. (2015) Quantifying confidence, National Bureau of Economic Research, Working Paper, No. 20807 and Centre for Economic Policy Research, Discussion Paper, No. 10463.

Beaudry, P., Deokwoo, N., and Wang, J. (2011) Do mood swings drive business cycles and is it rational?, Federal Reserve Bank of Dallas Globalization and Monetary Policy Institute, Working Paper, No. 98. 
Bernanke, B.S., and Reinhart, V.R. (2004) Conducting monetary policy at very low short-term interest rates, American Economic Review, 94, 85-90.

Blanchflower, D. (2008) Inflation, expectations and monetary policy, a presentation at the David Hume Institute of Royal Society of Edinburgh.

Carlstrom, C.T., Fuerst, T.S., and Paustian, M. (2012) Inflation and output in New Keynesian models with a transient interest rate peg, Working Paper, Federal Reserve Bank of Cleveland.

D'Amico, S., and King, T.B. (2013) Flow and stock effects on large-scale treasury purchases: evidence on the importance of local and supply, Journal of Financial Economics, 108, 425448.

Del Negro, M., Giannoni, M., and Patterson, C. (2013) The forward guidance puzzle, Federal Reserve Bank of New York Staff Papers, No. 574.

Eggertsson, G.B., and Woodford, M. (2003) The zero bound on interest rates and optimal monetary policy, Brookings Papers on Economic Activity, 1, 139-211.

Elliott, G., Rothenberg, T.J., and Stock, J.H. (1996) Efficient tests for an autoregressive unit root, Econometrica, 64, 813-836.

Fawley, B.W., and Neely, C.J. (2014) The evolution of Federal Reserve policy and the impact of monetary policy surprises on asset prices, Federal Reserve Bank of St. Louis Review, 96, 73-109.

Filardo, A., and Hofmann, B. (2014) Forward guidance at the zero lower bound, BIS Quarterly Review, 37-53.

Gambetti, L., and Musso, A. (2017) The macroeconomic impact of the ECB's expanded asset purchase programme (APP), European Central Bank Working Paper, No. 2075.

Hamilton, J.D., and Susmel, R. (1994) Autoregressive conditional heteroskedasticity and change in regime, Journal of Econometrics, 64, 307-333.

Koijen, R.S.J., Koulischer, F., Nguyen, B., and Yogo, M. (2016) Quantitative easing in the Euro area: the dynamics of risk exposures and the impact on asset prices, Banque de France Document de Travail Working Paper, No. 601.

Krishnamurthy A., and Vissing-Jorgensen, A. (2011) The effects of quantitative easing on interest rates: channels and implications for policy, Brookings Papers on Economic Activity, 2, 215-287.

Leduc, S. (2010) Confidence and the business cycle, Federal Reserve Bank of San Francisco, Economic Letter, No. 2010-35.

Mishkin, F. (2004) The Economics of Money, Banking, and Financial Markets, 8th ed. Boston: Addison-Wesley.

Neely, C. (2015) Unconventional monetary policy had large international effects, Journal of Banking and Finance, 52, 101-111.

Schmitt-Grohé, S., and Uribe, M. (2007) Optimal inflation stabilization in a medium-scale macroeconomic model, in Monetary Policy under Inflation Targeting, Schmidt-Hebbel, K., and Mishkin, R., 125-186, Central Bank of Chile, Santiago.

Task Force of the Monetary Policy Committee of the European System of Central Banks (2012) Euro area labour markets and the crisis, European Central Bank, Working Paper, No. 138.

Woodford, M. (2001) The Taylor rule and optimal monetary policy, American Economic Review, 91, 232-237. 